\title{
Identifying the Relationships between Water Quality and Land Cover Changes in the Tseng-Wen Reservoir Watershed of Taiwan
}

\author{
Hone-Jay Chu *, Chun-Yu Liu and Chi-Kuei Wang \\ Department of Geomatics, National Cheng Kung University, No. 1, University Road, Tainan City 701, \\ Taiwan; E-Mails: cute_chunyu_0527@hotmail.com (C.-Y.L.); chikuei@mail.ncku.edu.tw (C.-K.W.) \\ * Author to whom correspondence should be addressed; E-Mail: honejaychu@gmail.com; \\ Tel.: +886-6-275-7575 (ext. 63827); Fax: +886-6-237-5764.
}

Received: 22 September 2012; in revised form: 31 December 2012 / Accepted: 21 January 2013 / Published: 28 January 2013

\begin{abstract}
The effects on water quality of land use and land cover changes, which are associated with human activities and natural factors, are poorly identified. Fine resolution satellite imagery provides opportunities for land cover monitoring and assessment. The multiple satellite images after typhoon events collected from 2001 to 2010 covering land areas and land cover conditions are evaluated by the Normalized Difference Vegetation Index (NDVI). The relationship between land cover and observed water quality, such as suspended solids (SS) and nitrate-nitrogens $\left(\mathrm{NO}_{3}-\mathrm{N}\right)$, are explored in the study area. Results show that the long-term variations in water quality are explained by NDVI data in the reservoir buffer zones. Suspended solid and nitrate concentrations are related to average NDVI values on multiple spatial scales. Annual $\mathrm{NO}_{3}-\mathrm{N}$ concentrations are positively correlated with an average NDVI with a $1 \mathrm{~km}$ reservoir buffer area, and the SS after typhoon events associated with landslides are negatively correlated with the average NDVI in the entire watershed. This study provides an approach for assessing the influences of land cover on variations in water quality.
\end{abstract}

Keywords: remote sensing; NDVI; water quality; land cover change; regression 


\section{Introduction}

Land use and land cover changes, associated with human activities and natural factors, compromise many ecosystem services in a watershed [1,2]. For example, forestland converted to agricultural or urban land may have increased erosion, runoff, and flooding [3]. Changes in land use and land cover interact with anthropogenic and natural drivers to affect the water quality of watersheds. Studies have used environmental and landscape data to examine the relationships between land use and land cover changes and suspended sediments [4-7] and nutrients [1,7-10]. Ahearn et al. showed that land use and land cover exert the greatest control over water quality in the Cosumnes Watershed, California [7]. The percentage of agricultural coverage had a significant influence on nutrient loading. Sliva and Williams used multivariate analysis to determine whether there was a correlation between water quality and landscape characteristics within the local Southern Ontario watersheds in Canada. They compared the influences of buffer zones and whole catchment landscape characteristics on water quality [9]. Li et al. showed the impact of land use and land cover on the water quality in the Upper Han River basin, China [10]. The correlation and regression analysis indicated that water quality was significantly related to vegetated coverage.

Water quality is controlled by numerous anthropogenic and natural factors [7]. The quality of receiving waters is affected by human activities in a watershed by point sources, such as wastewater treatment facilities, and non-point sources, such as runoff from urban areas and farmland [11]. Understanding non-point source pollution requires an understanding of how particular land covers influence water quality within a watershed. The extent that land covers hierarchically affect water quality at space-time scales is a key question. The most widely used land cover index in this context is the normalized difference vegetation index (NDVI), which is a function of red and near-infrared spectral bands [12]. On a regional scale, multi-temporal NDVI images are practical for monitoring vegetation dynamics. The multi-temporal NDVI is useful for classifying land cover and detecting the dynamics of vegetation $[13,14]$. However, major changes in the NDVI are noted near landslides that were induced by disturbances in Taiwan $[15,16]$. For example, a typhoon is one of major natural disturbances to land cover. Sequent typhoons and rainstorms cause abnormal destruction to the vegetation; this destruction is influenced by rainfall distributions and typhoon paths [15].

The NDVI data were derived from SPOT satellite images in the Tseng-Wen Reservoir Watershed, Taiwan, before and after Typhoon Morakot and several other large typhoons (e.g., Typhoon Mindulle in 2004, Haitang in 2005, Sepat in 2007, Kalmaegi in 2008, and Fanapi in 2010) [17] to identify the changes to land cover. To represent land use and land cover change, an evaluation of multiple NDVI spatial scales was conducted. The study identified and delineated the relationships between temporal variations of the NDVI and water quality in the study area.

\section{Materials and Methods}

\subsection{Study Area}

The Tseng-Wen Reservoir is a multipurpose reservoir designed for flood control, hydroelectric power generation, irrigation, water supply, recreation, and flow augmentation. The storage capacity of the Tseng-Wen reservoir is $608 \times 10^{6} \mathrm{~m}^{3}$, but its effective water storage is $490 \times 10^{6} \mathrm{~m}^{3}$, and the 
hydroelectric plant capacity is $50 \mathrm{MW}$. The Tseng-Wen Reservoir Basin is located in the upstream area of the Tseng-Wen River system in Chiayi County (Figure 1). The entire watershed area of this river basin is $1,176 \mathrm{~km}^{2}$, in which the Tseng-Wen Reservoir watershed covers $481 \mathrm{~km}^{2}$. The average slope of this river basin is approximately $1 / 57$. Average rainfall in this watershed area is approximately $3,000 \mathrm{~mm}$ per year and annual average temperature is about $23.4^{\circ}$ Celsius. Rich soil in the watershed is suitable for fruit and tea farms. Agriculture has restricted near the reservoir but tourism has developed in recent years.

Numerous major typhoons have struck Taiwan, such as Typhoon Mindulle in 2004, Haitang in 2005, Sepat in 2007, Kalmaegi in 2008, Morakot in 2009, and Fanapi in 2010 [17]. Especially, Typhoon Morakot struck Taiwan from 7 to 9 August, 2009, and produced record-breaking rainfall and catastrophic damage in Southern Taiwan. The typhoon produced copious amounts of rainfall peaking at 2,777 $\mathrm{mm}$.

Figure 1. Location of Tseng-Wen Reservoir watershed and water quality sampling stations.

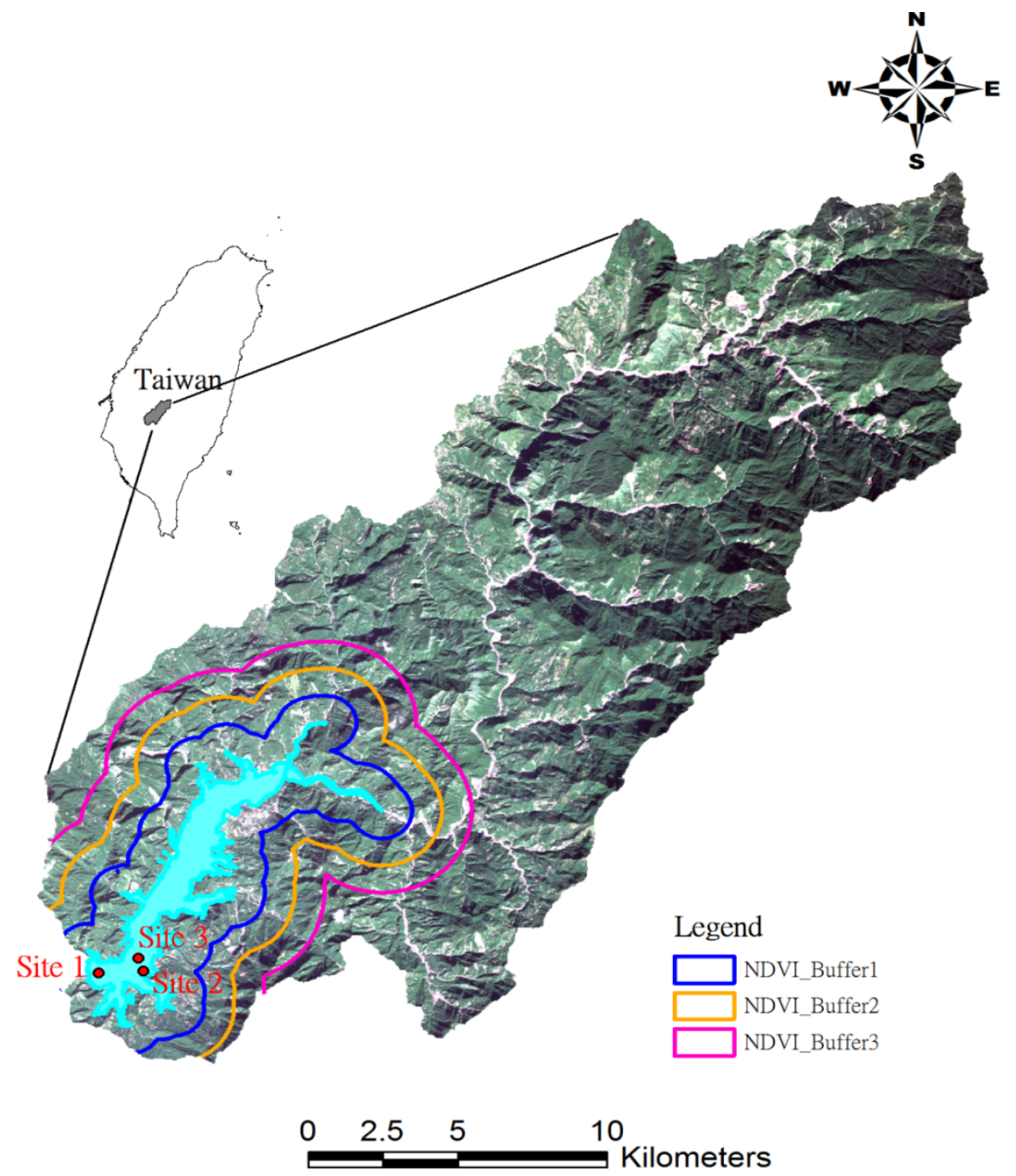

\subsection{Satellite Images}

Multi-temporal Système Pour l'Observation de la Terre (SPOT) satellite images obtained after typhoons in 2001, 2003-2005, and 2007-2010 were used to quantify land cover changes in our study. Details for the dates are listed in Table 1. For atmospheric correction, Fast Line of Sight Atmospheric 
Analysis of Spectral Hypercube (FLAASH) is applied to correct the visible and near-infrared wavelengths in the satellite images [18]. Then, the NDVI maps were derived from the SPOT images taken in 2001 with a $20 \mathrm{~m}$ resolution, and with a $10 \mathrm{~m}$ resolution in 2003-2010. Moreover, the SPOT images were classified using supervised classification by the software package ERDAS IMAGINE. Land-use types were classified into the following six categories: forested land, built-up land, landslide, grassland, water, and bare land [19]. The reference maps were the aerial photographs by the Aerial Survey Office, Forestry Bureau, Taiwan.

Table 1. Mean and standard deviation of NDVI maps during 2001-2010.

\begin{tabular}{cccc}
\hline & Date & Mean & SD \\
\hline 2001 & $2001 / 10 / 22$ & 0.585 & 0.205 \\
\hline 2003 & $2003 / 12 / 30$ & 0.704 & 0.163 \\
\hline 2004 & $2004 / 12 / 29$ & 0.600 & 0.171 \\
\hline 2005 & $2005 / 11 / 05$ & 0.663 & 0.191 \\
\hline 2007 & $2008 / 01 / 05$ & 0.563 & 0.209 \\
\hline 2008 & $2008 / 11 / 12$ & 0.686 & 0.171 \\
\hline 2009 & $2009 / 11 / 01$ & 0.437 & 0.218 \\
\hline 2010 & $2010 / 12 / 27$ & 0.494 & 0.221 \\
\hline
\end{tabular}

SD: standard deviation.

\subsection{Water Quality Data}

Seasonal time series of water-quality data monitored in the reservoir were obtained from Taiwanese EPA Web sites [20]. The water quality data observed at three stations were obtained from 2001 to 2010 and data sampling frequency was three months. The sampling sites are shown in Figure 1. The water-quality variables, such as nitrate-nitrogen $\left(\mathrm{NO}_{3}-\mathrm{N}\right)$, suspended sediments $(\mathrm{SS})$, chemical oxygen demand (COD), dissolved oxygen (DO), total phosphorus (TP), and turbidity, were derived for analysis. The variables are used as general indicators of water quality. For example, the COD is commonly used to measure the amount of organic compounds in water. As the DO in water drops below a threshold, aquatic life is under stress. The presence of high nitrates and TP concentrations in water indicates possible pollution of the water. Turbidity is the haziness of a fluid caused by the SS, which are solid particles usually transported by flowing water.

\subsection{Regression Model}

Reservoir water chemistry was sampled at the outlets and downstream of the reservoir every three months. We refer to the water samples after typhoons in the fourth season and acquire annual values each year. We ran a series of models to examine the correlations between land-cover and the water quality variables.

Our basic statistical tool was stepwise multiple linear regression, with backward selection of variables and $p=0.1$ to enter or remove variables. Cases with missing data were excluded. Statistical analyses were done using SPSS 10.0. The dependent (response) variables are $\mathrm{NO}_{3}-\mathrm{N}$ and SS concentrations that are selected from the high-NDVI correlated water quality factors. The variable 
details are shown in Section 3.2. In addition, the independent variables are average NDVI at various spatial scales such as average NDVI in whole watershed, average NDVI in reservoir $1 \mathrm{~km}, 2 \mathrm{~km}$ and $3 \mathrm{~km}$ buffer zones, can be represented as:

$$
\overline{\operatorname{NDVI}}(t)=\sum_{s \in S} \operatorname{NDVI}(s, t) / \mathrm{num}
$$

where $\operatorname{NDVI}(s, t)$ represent NDVI value varies with space $s$ and time $t ; \overline{N D V I}(t)$ is average NDVI in whole watershed or reservoir buffer zone during time $t$; $S$ is the domain set that defined as whole watershed or reservoir buffer zone; num is the number of the pixels in the set $S$.

\section{Results and Discussion}

\subsection{Temporal Land Use and NDVI Changes}

Figure 2 shows that land use classification in 2001, 2004, 2007 and 2010. The forested land, grassland, bare land, build-up, and landslide accounted for $77.61 \%, 11.72 \%, 7.72 \%, 2.55 \%$ and $0.42 \%$ (excluding water) of the total watershed area in 2001, respectively. During 2001-2010, forest has decreased $4.81 \%$, grassland has increased $2.35 \%$, landslide has increased $2.12 \%$, bare land has increased $0.55 \%$, and built-up land has decreased $0.21 \%$ (Figure 3 ). The results matched previous studies $[21,22]$ that many landslides in the Tseng-Wen reservoir watershed were caused by typhoons. Table 1 shows the statistics of NDVI images after typhoon events from 2001 to 2010. Results show that the lowest mean NDVI values (0.437) occurred on November 1, 2009, after Typhoon Morakot, and the second lowest NDVI values occurred on December 27, 2010 (0.494). The greatest impact on the landscape is from Typhoons Morakot and Fanapi. During the event (i.e., Typhoon Fanapi), the standard deviation of NDVI values was the largest. The analysis results of NDVI images (Figure 4) are sufficient to present land cover changes induced by disturbances, particularly by spatial structure, variability, and spatial correlation. The disturbances impacted the fragmentation and interspersion of the low NDVI patches and created heterogeneous patterns across the landscape within the affected area [16]. However, land cover change may be different in the spatial scales. The box plot shows that the range between the lower and upper quartiles in the NDVI decreases when the buffer zone increases (Figure 5).

\subsection{The Change of Water Quality}

Table 2 shows the correlation coefficients between the average NDVI in the watershed and average water quality factors during the whole year and after typhoon. The average value of the NDVI in the watershed is strongly correlated with $\mathrm{NO}_{3}-\mathrm{N}$ during the entire year and is strongly correlated with SS after typhoon from 2001 to 2010. These water quality factors such as $\mathrm{SS}$ and $\mathrm{NO}_{3}-\mathrm{N}$ concentrations are the indices for water quality assessment when considering land cover changes. The average SS concentrations after typhoons and the average annual $\mathrm{NO}_{3}-\mathrm{N}$ in the sites are used by later descriptive statistics and regression analysis. 
Figure 2. Land use classification in (a) 2001, (b) 2004, (c) 2007 and (d) 2010.

(a)

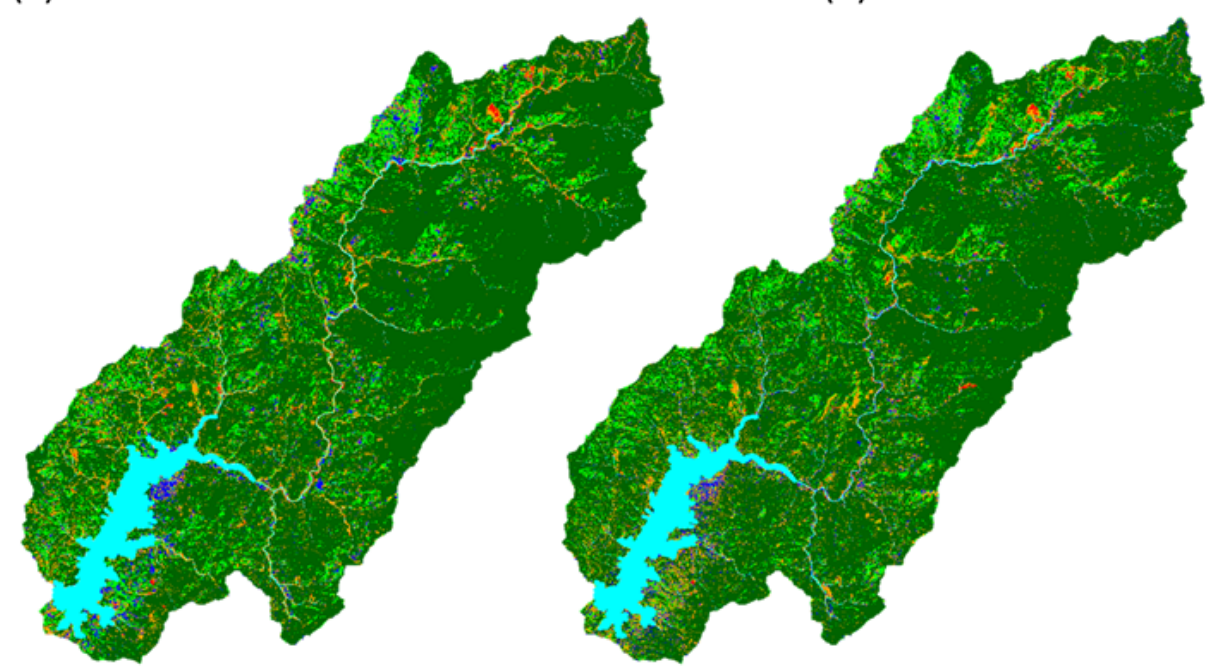

(c)

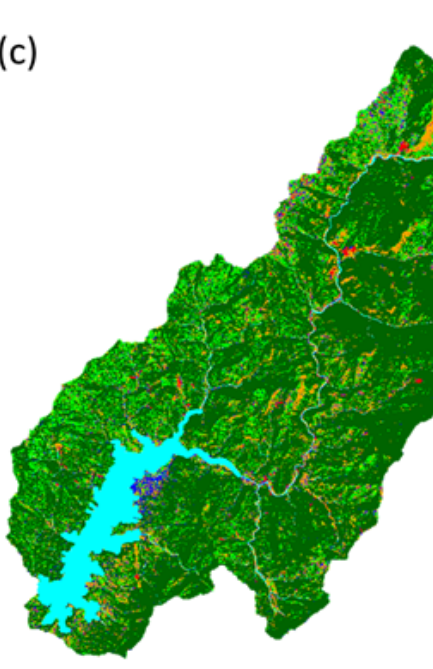

(b)

(d)

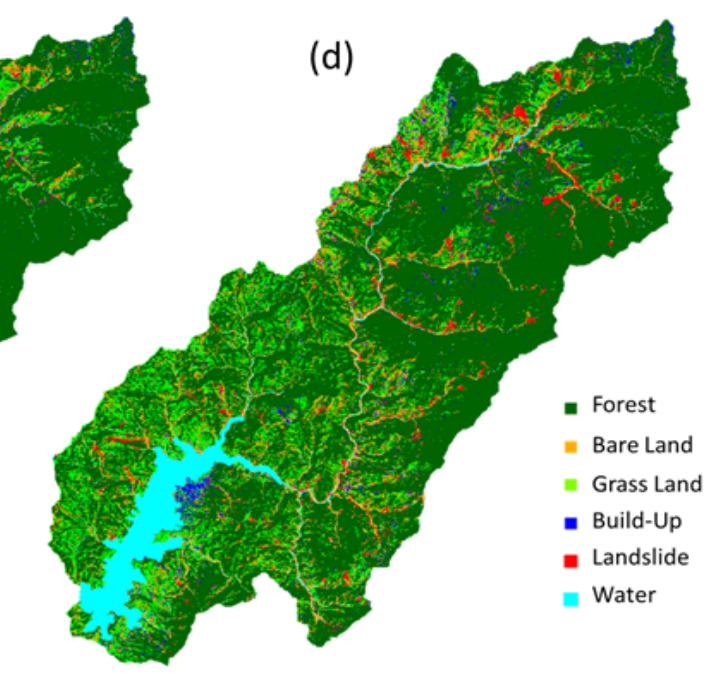

Figure 3. Land use change percentage from 2001 to 2010.

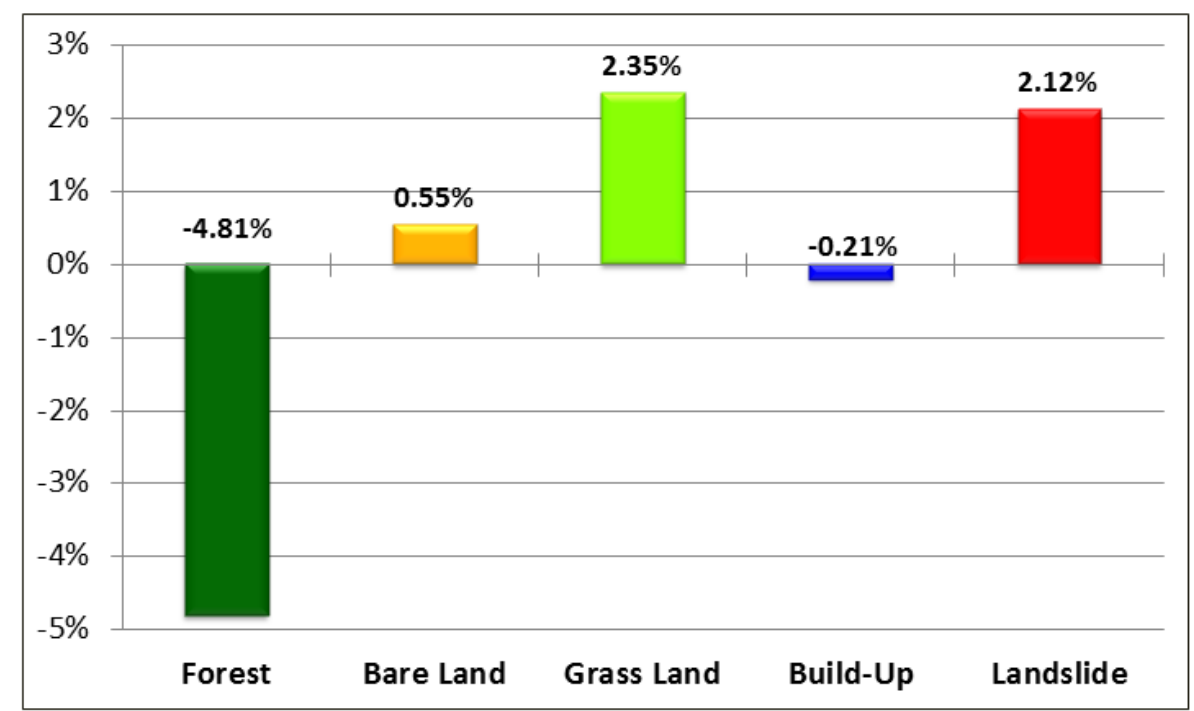


Figure 4. Images of NDVI patterns in the study area during (a) 2001, (b) 2003, (c) 2004, (d) 2005, (e) 2007, (f) 2008, (g) 2009 and (h) 2010.
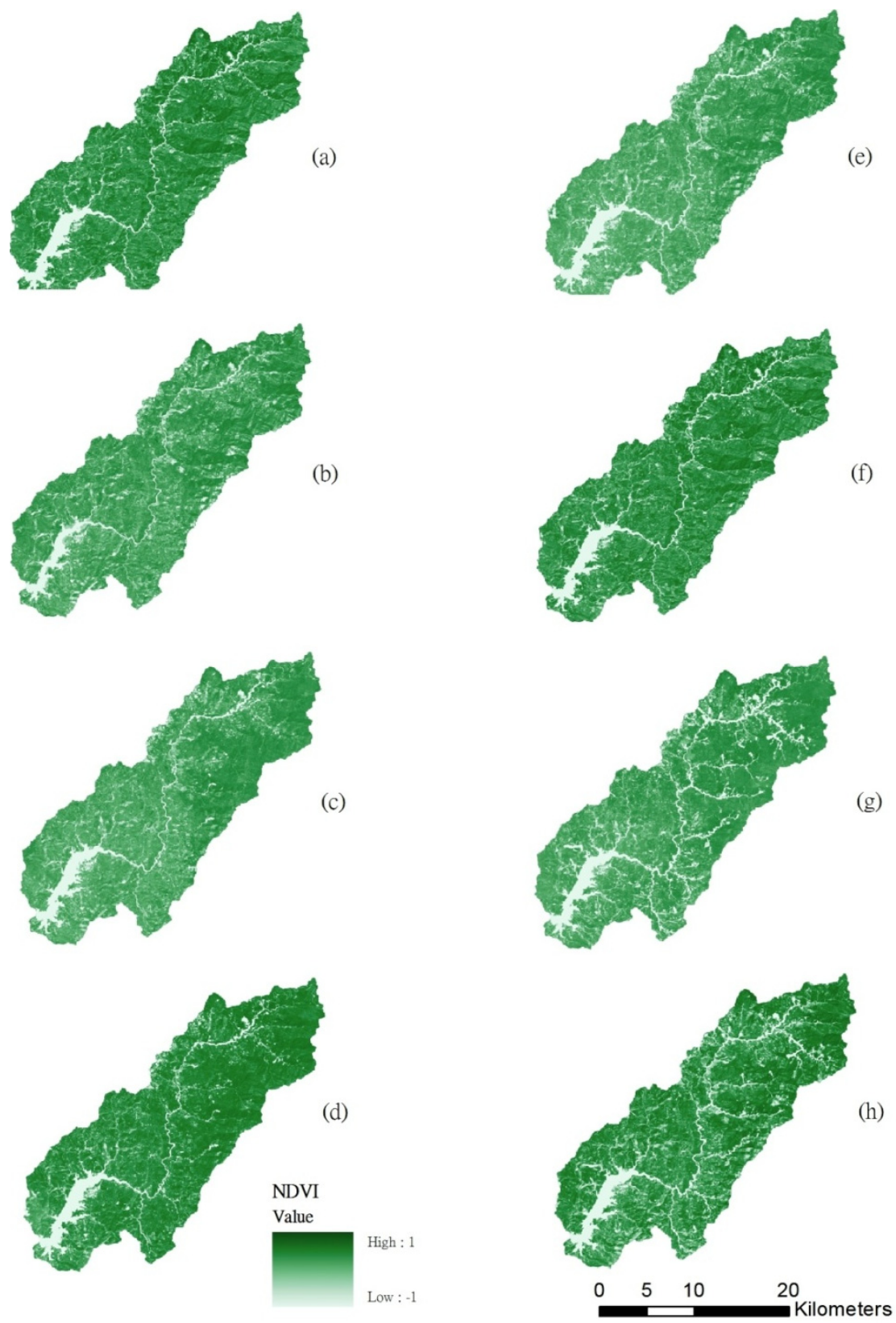

Figure 5. Boxplot of NDVI values for (a) 1, (b) 2, and (c) $3 \mathrm{~km}$ buffer zones.

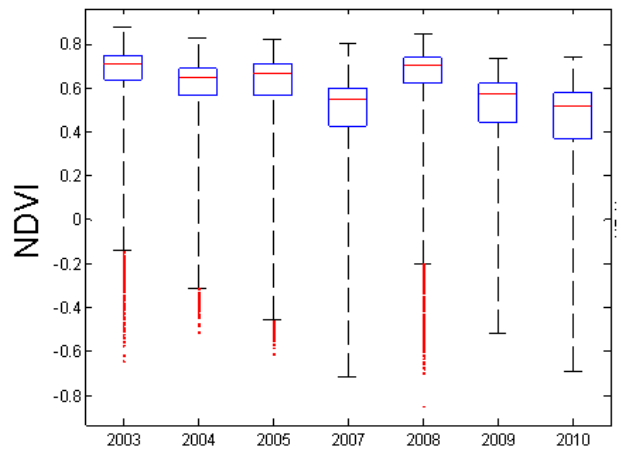

(a)

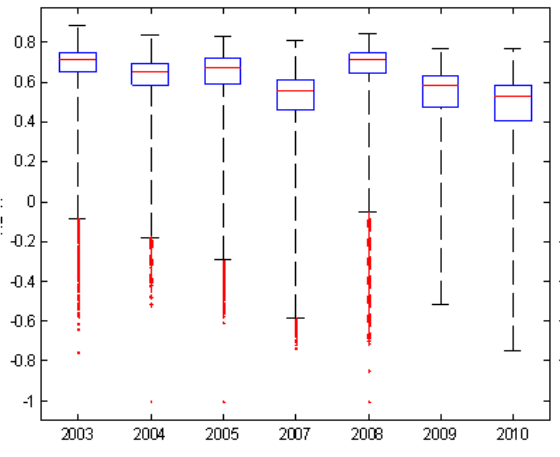

(b)

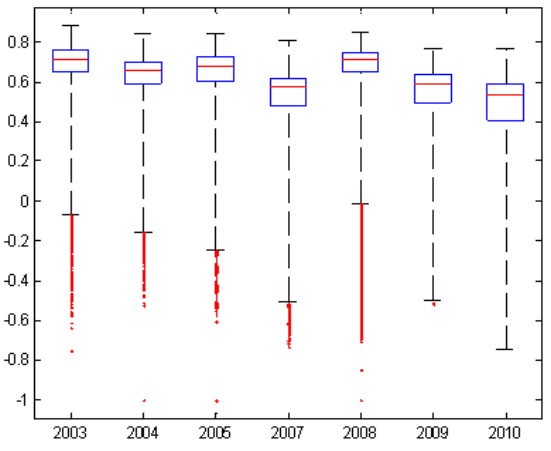

(c) 
Table 2. Correlation coefficients of average NDVI and water quality in whole year and after typhoon.

\begin{tabular}{ccccccc}
\cline { 2 - 7 } & NO $_{\mathbf{3}}-\mathbf{N}$ & SS & COD & DO & TP & Turbidity \\
\hline Whole year & 0.687 & -0.577 & 0.277 & -0.498 & 0.313 & 0.086 \\
\hline After typhoon & 0.529 & -0.621 & 0.604 & -0.060 & 0.364 & -0.384 \\
\hline
\end{tabular}

NO3-N: nitrate-nitrogen; SS: suspended sediments; COD: chemical oxygen demand; DO: dissolved oxygen; TP: total phosphorus.

Table 3. Descriptive statistics of $\mathrm{SS}$, and $\mathrm{NO}_{3}-\mathrm{N}$ data in three water quality-monitoring stations during 2001-2010.

\begin{tabular}{lrrrrrrr}
\cline { 3 - 7 } & & Mean & SD & Q25 & Q75 & Min & Max \\
\hline \multirow{2}{*}{$\begin{array}{l}\text { SS } \\
(\mathrm{ppm})\end{array}$} & Site 1 & 4.51 & 2.47 & 2.90 & 5.70 & 0.80 & 13.50 \\
\cline { 2 - 7 } & Site 2 & 4.85 & 2.61 & 3.10 & 6.05 & 1.10 & 12.60 \\
\cline { 2 - 7 } & Site 3 & 4.52 & 2.14 & 2.90 & 5.78 & 1.00 & 9.80 \\
\hline $\mathrm{NO}_{3}-\mathrm{N}$ & Site 1 & 0.44 & 0.31 & 0.25 & 0.58 & 0.01 & 1.62 \\
\cline { 2 - 8 }$(\mathrm{ppm})$ & Site 2 & 0.47 & 0.30 & 0.26 & 0.60 & 0.01 & 1.45 \\
\cline { 2 - 7 } & Site 3 & 0.45 & 0.28 & 0.28 & 0.58 & 0.01 & 1.20 \\
\hline
\end{tabular}

SD: standard deviation; Q25: the first quartile; Q75: the third quartile; Min: minimum; Max: maximum.

Figure 6. Temporal variation of (a) SS and (b) $\mathrm{NO}_{3}-\mathrm{N}$ during 2001 and 2010 (unit: ppm).

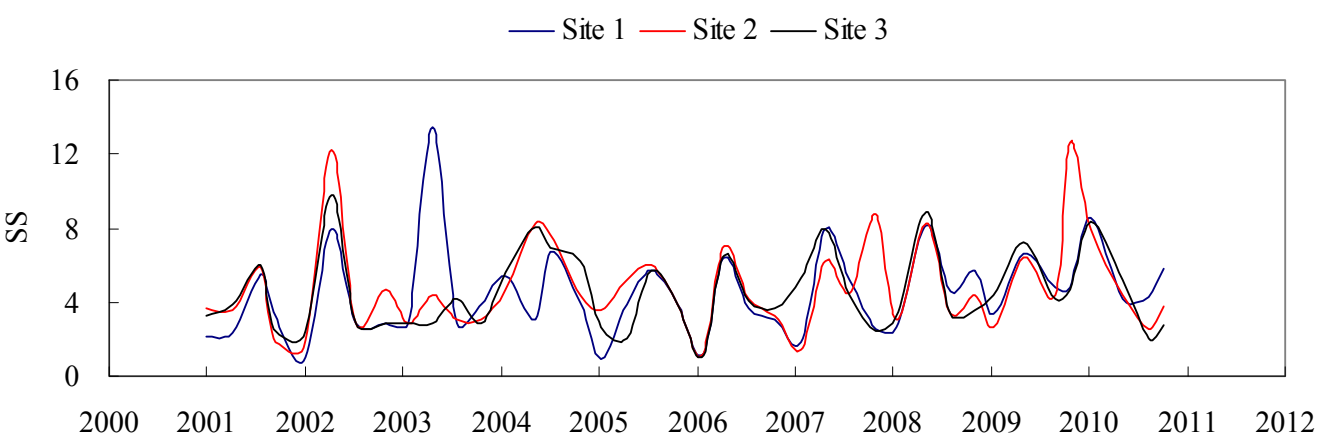

(a)

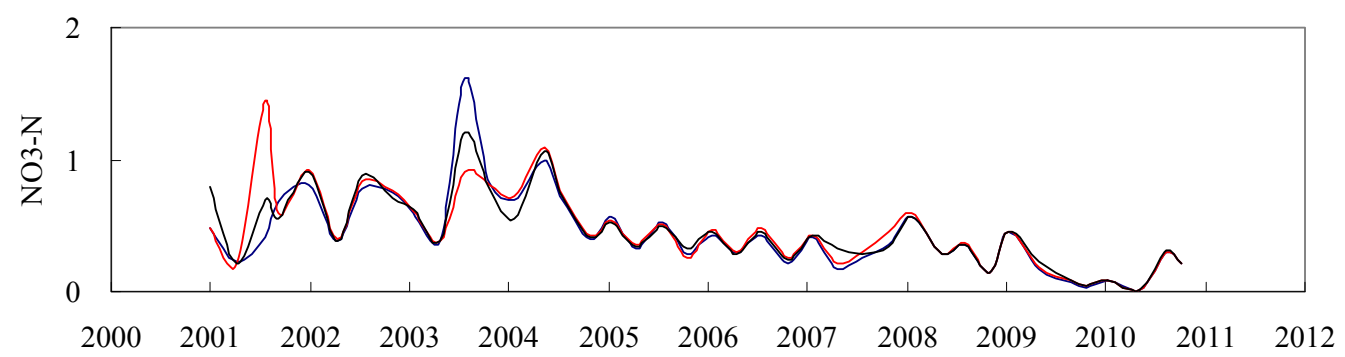

(b)

Table 3 lists quarterly measurements of $\mathrm{SS}$, and $\mathrm{NO}_{3}-\mathrm{N}$ data at three water quality-monitoring stations from 2001 to 2010 (Figure 6). The average concentrations for SS for observation Sites 1, 2, and 3 are in the ranges of $0.8-13.5(\mathrm{ppm}), 1.1-12.6(\mathrm{ppm})$, and 1.0-9.8 (ppm), respectively. Moreover, the average concentration of $\mathrm{NO}_{3}-\mathrm{N}$ for Sites 1, 2, and 3 are in the ranges of 0.01-1.62 (ppm), 0.01-1.45 (ppm), and 0.01-1.20 (ppm), respectively. The average SS values are 4.51, 4.85, and $4.52(\mathrm{ppm})$, and the average $\mathrm{NO}_{3}-\mathrm{N}$ values are $0.44,0.47$, and $0.45(\mathrm{ppm})$ in these 3 sites. Figure 6(a) shows that SS 
concentrations are cyclical. Typhoons and heavy rainfalls trigger large sediment discharge into the rivers of Taiwan and cause high-suspended sediment concentrations during these events. Most nitrate concentrations in the water drains from agricultural land. However, Figure 6(b) shows $\mathrm{NO}_{3}-\mathrm{N}$ concentrations vary with a decreasing trend.

\subsection{Relationship between SS Concentration and Land Cover Change}

Table 4 shows the regression models for water quality and land cover changes at various spatial scales. The factors comprise the average NDVI in the watershed, and the average NDVI in $1 \mathrm{~km}, 2 \mathrm{~km}$, and $3 \mathrm{~km}$ buffer zones. Results show that annual nitrate-nitrogen concentrations are positively correlated with the NDVI with a $1 \mathrm{~km}$ buffer area. However, SS is negatively impacted by the average NDVI in the watershed, suggesting that typhoons impact land cover change in the watershed. For example, typhoons cause landslides, and these are a major source of soil erosion and sediment yield in the watershed. The average NDVI in the watershed adversely impacts the water quality, and therefore, increases sediments associated with water quality. The average NDVI in the watershed becomes a key factor influencing the SS concentration. Typhoon events are major natural disturbances causing NDVI changes and also cause serious landslides [16,23,24]. Both important factors affecting soil erosion and sediment delivery to river channels are changes in land use and climate. Due to destruction of vegetation and increased soil exposure in the watershed after rainstorms and typhoons, the NDVI values decreased. The rainstorms and typhoons cause divergent destruction of vegetation, and led to an increase in the potential for soil erosion.

Table 4. Regression model for the function of water quality and average NDVI in various scales.

\begin{tabular}{lcc}
\cline { 2 - 3 } & $\mathbf{S S}$ & $\mathbf{N O}_{3}-\mathbf{N}$ \\
\hline Const. & 6.86 & -0.73 \\
\hline NDVI_Watershed & $-23.74 *$ & - \\
\hline NDVI_Buffer1 & - & $2.10^{*}$ \\
\hline NDVI_Buffer2 & - & - \\
\hline NDVI_Buffer3 & 20.23 & - \\
\hline$R^{2}$ & 0.65 & 0.75 \\
\hline
\end{tabular}

* represents $p<0.05$

NDVI_Watershed: average NDVI in whole watershed; NDVI_Buffer1: average value of NDVI in $1 \mathrm{~km}$ buffer zone; NDVI_Buffer2: average value of NDVI in $2 \mathrm{~km}$ buffer zone; NDVI_Buffer3: average value of NDVI in $3 \mathrm{~km}$ buffer zone.

\subsection{Relationship Between $\mathrm{NO}_{3}-\mathrm{N}$ Concentration and Land Cover Change}

Results show that the dominant explanatory variables in $\mathrm{NO}_{3}-\mathrm{N}$ cases have an average NDVI with a $1 \mathrm{~km}$ buffer zone. In some reservoirs and lakes, the primary indicator of agriculture is dependent on $\mathrm{NO}_{3}-\mathrm{N}$ concentration. The nitrate concentration is correlated with agricultural practices during the high-flow period. Human activity alters the patterns of nitrate concentrations during storm events in the agricultural catchment [25]. Since Taiwan joined the World Trade Organization (WTO) in 2002, imported agricultural products are cheaper than domestic ones, thus negating the need for extensive 
agriculture areas. This corresponds to the data that tea farms in Chiayi County decreased from 2,292 to 2,189 ha from 2005 to 2011 [26]. Forestry, agriculture, and anthropogenic activities impact the quality of water over short and long periods [27]. The $\mathrm{SS}$ and $\mathrm{NO}_{3}-\mathrm{N}$ are typically sensitive in landslide and agriculture land areas. The previous results match that percent agricultural coverage had a significant influence on both SS and nitrate-N loading [7]. NDVI variation results imply that as land cover changes; hence, the multi-scale NDVI, which is one of the indices in the watershed of land cover changes, is associated with water quality and is hard to directly link with agriculture. However, the land use classification of SPOT images is also hard to identify the agriculture land. Further study could consider the high-resolution satellite images in the land use classification.

\section{Conclusions}

This study examined the NDVI images from 2001 to 2010 based on SPOT imagery data. The imagery shows that the land cover changes in the study vary with the influences of typhoons and human activities. Satellite image data showed a general decline in the acreage of vegetation cover implying increased landslide and decreased forest pressure on the vegetation resources.

Land cover change had a significant influence on both suspended solid and nitrate-nitrogen loadings. Simple regressions were performed that showed water quality is related to land cover in various spatial scales. Annual $\mathrm{NO}_{3}-\mathrm{N}$ concentration is positively correlated with an average NDVI with a reservoir $1 \mathrm{~km}$ buffer area, but SS are negatively correlated with an average NDVI in the watershed after typhoon events. Understanding the relationship between land cover change and water quality is useful for watershed management and pollution prevention plans. Further study should add additional spatial and independent variables to the models, such as percentage of land use type, anthropogenic activities and typhoon precipitation.

\section{Acknowledgment}

The authors would like to thank Dept. of Land Administration, Ministry of Interior and National Science Council, Taiwan (No. NSC 100-2218-E-006-021) for financially supporting this research. This research received funding from the Headquarters of University Advancement at the National Cheng Kung University, which is sponsored by the Ministry of Education, Taiwan. We also thank editors, many helpers and the Taiwanese EPA for providing the monitoring data and Center for Space \& Remote Sensing Research, NCU for image processing assistance.

\section{References}

1. Allan, J.D.; Erickson, D.L.; Fay, J. The influence of catchment land use on stream integrity across multiple spatial scales. Freshwater Biol. 1997, 37, 149-161.

2. Burcher, C.L.; Valett, H.M.; Benfield, E.F. The land-cover cascade: Relationships coupling land and water. Ecology 2007, 88, 228-242.

3. Prato, T. Selection and evaluation of projects to conserve ecosystem services. Biol. Modelling 2007, 203, 290-296. 
4. Allan, J.D.; Erickson, D.L.; Fay, J. The influence of catchment land use on stream integrity across multiple spatial scales. Freshwater Biol. 1997, 37, 149-161.

5. Bolstad, P.V.; Swank, W.T. Cumulative impacts of landuse on water quality in a southern Appalachian watershed. J. Am. Water Resour. Assoc. 1997, 33, 519-533.

6. Johnson, L.B.; Richards, C.; Host, G.E.; Arthur, J.W. Landscape influences on water chemistry in midwestern stream ecosystems. Freshwater Biol. 1997, 37, 193-208.

7. Ahearn, D.S.; Sheibley, R.S.; Dahlgren, R.A.; Anderson, M.; Jonson, J.; Tate, K.W. Land use and land cover influence on water quality in the last free-flowing river draining the western Sierra Nevada, California. J. Hydrol. 2005, 313, 234-247.

8. Osborne, L.L.; Wiley, M.J. Empirical relationships between land-use cover and stream water-quality in an agricultural watershed. J. Environ. Manage. 1988, 26, 9-27.

9. Sliva, L.; Williams, D.D. Buffer zone versus whole catchment approaches to studying land use impact on river water quality. Water Res. 2001, 35, 3462-3472.

10. Li, S.Y.; Gu, S.; Liu, W.Z.; Han, H.Y.; Zhang, Q.F. Water quality in relation to land use and land cover in the upper Han River Basin, China. CATENA 2008, 75, 216-222.

11. Wang, X. Integrating water-quality management and land-use planning in a watershed context. J. Environ. Manage. 2001, 61, 25-36.

12. Stefanov, W.L.; Netzband, M. Assessment of ASTER land cover and MODIS NDVI data at multiple scales for ecological characterization of an arid urban center. Remote Sen. Environ. 2005, 99, 31-43.

13. Legendre, P.; Legendre, L. Numerical Ecology; Elsevier: Amsterdam, The Netherlands, 1998.

14. Senay, G.B.; Elliott, R.L. Combining AVHRR-NDVI and landuse data to describe temporal and spatial dynamics of vegetation. Forest Ecol. Manage. 2000, 128, 83-91.

15. Lin, Y.P.; Chu, H.J.; Wang, C.L.; Yu, H.H.; Wang, Y.C. Remote sensing data with the conditional Latin hypercube sampling and geostatistical approach to delineate landscape changes induced by large chronological physical disturbances. Sensors 2009, 9, 148-174.

16. Chu, H.J.; Lin, Y.P.; Huang, Y.L.; Wang, Y.C. Detecting the land-cover changes induced by large-physical disturbances using landscape metrics, spatial sampling, simulation and spatial analysis. Sensors 2009, 9, 6670-6700.

17. Typhoon Database in Taiwan. Available online: http://rdc28.cwb.gov.tw/ (accessed on 22 September 2012).

18. ENVI Atmospheric Correction Module: QUAC and FLAASH User's Guide. Available online: http://www.exelisvis.com/portals/0/pdfs/envi/Flaash_Module.pdf (accessed on 22 September 2012).

19. Chu, H.J.; Liu, C.Y.; Wang, C.K. Relationship between Land Cover and Water Quality in Tseng-Wen Reservoir Watershed, Taiwan. In Proceedings of the 33rd Asian Conference on Remote Sensing (ACRS 2012), Pattaya, Thailand, 26-30 November 2012.

20. Taiwanese Environmental Protection Administration (EPA) Websites. Available online: http://taqm.epa.gov.tw/taqm/zh-tw/default.aspx (accessed on 22 September 2012).

21. Galewsky, J.; Stark, C.P.; Dadson, S.; Wu, C.C.; Sobel, A.H.; Horng, M.J. Tropical cyclone triggering of sediment discharge in Taiwan. J. Geophys. Res. Earth Surf. 2006, 111, doi: 10.1029/ 2005JF000428. 
22. Ward, P.; van Balen, R.T.; Verstraeten, G.; Renssen, H.; Vandenberghe, J. The impact of land use and climate change on late Holocene and future suspended sediment yield of the Meuse catchment. Geomorphology 2008, 103, 389-400.

23. Borghuis, A.M.; Chang, K.; Lee, H.Y. Comparison between automated and manual mapping of typhoon-triggered landslides from SPOT-5 imagery. Int. J. Remote Sens. 2007, 28, 1843-1856.

24. Liu, C.C.; Shieh, C.L.; Lin, J.C.; Wu, A.M. Classification of non-vegetated areas using Formosat-2 high spatiotemporal imagery: The case of Tseng-Wen Reservoir catchment area (Taiwan). Int. J. Remote Sens. 2011, 32, 8519-8540.

25. Poor, C.J.; McDonnell, J.J. The effects of land use on stream nitrate dynamics. J. Hydrol. 2007, 332, 54-68.

26. Agriculture and Food Agency, Council of Agriculture, Executive Yuan, Taiwan. Available online: http://www.afa.gov.tw/GrainStatistics_index.asp (accessed on 22 September 2012).

27. Pekárová, P.; Pekár, J. The impact of land use on stream water quality in Slovakia. J. Hydrol. 1996, $180,333-350$.

(C) 2013 by the authors; licensee MDPI, Basel, Switzerland. This article is an open access article distributed under the terms and conditions of the Creative Commons Attribution license (http://creativecommons.org/licenses/by/3.0/). 